\title{
Hospitality, Protection and Refuge in Early English Law ${ }^{1}$
}

\begin{abstract}
This article explores the ideas and values which underpinned legally recognised practices of providing protection to the vulnerable in Anglo-Saxon England (c.500-1066). Prominent among these is sanctuary in churches but this should be understood as part of a wider tradition of offering refuge to those in danger, rooted in secular notions of hospitality and honour. Membership of a community in this period inhered in legally binding social relationships - reciprocal ties of kinship and hierarchical bonds modelled on the household - which simultaneously protected individuals from harm and established local sureties obliged to make good any harm they did. Outsiders, lacking such relationships, were both threatening and vulnerable. Hospitality was exceptional, in that hosts were entitled to protect guests without becoming liable for their actions. This allowed them to provide refuge to the vulnerable, from refugees to thieves, and the Anglo-Saxon elite may well have felt honour-bound to do so, but it was necessarily temporary. The host-guest relationship expired after a few days, theoretically leaving thieves in danger and refugees needing to form less advantageous but sustainable long-term relationships.
\end{abstract}

\section{Introduction}

One of the most well-known features of medieval law is the refuge function of churches, which though specific rules varied significantly in different times and places - were often able to offer powerful protection to those who fled to them. Indeed, medieval practices of ecclesiastical sanctuary are traditionally understood as antecedents to modern political asylum (e.g. Price 2009). Whether or not this view is justified is a question for historians of later periods. This article explores the social and cultural logic which underpinned the refuge function of churches in England during the Anglo-Saxon period (c.500-1066), not only because it is valuable to understand ecclesiastical sanctuary as part of its broader environment but also because the issues which this exploration raises are close to the core concerns of this volume. To understand the refuge function of churches in this period, I would like to argue, we need to understand what it meant to be an outsider - a foreigner or a stranger - in English society, the reasons such people were a source of anxiety, and the methods by which they could be protected and integrated both in the short and long term.

Moreover, I would contend that it is through these ideas that we can get closest to understanding the situation of people whom modern observers might be tempted to label 'refugees'. Forced exile appears to have been a common outcome of internal conflict in this period, though in an early medieval context it is perhaps particularly unlikely that a sharp distinction existed between 'political' refugees and those whose exile was a consequence of ordinary wrongdoing (cross reference Orchard). It is also worth noting that, especially in its early centuries, the Anglo-Saxon period witnessed a great deal of warfare, some of which may well have produced refugees; in a couple of cases, at any rate, our sources' descriptions have led historians to use terms such as 'ethnic cleansing' (Campbell 2000: 34-5). The likelihood is that refugees existed in this period; the problem is that we do not have the sources to study them directly. The best we can do is investigate the legal and cultural framework which would have shaped the way refugees, as outsiders, were understood and treated. We may not be able to study early medieval refugees themselves, but we do have access to at least some of the ideas and structures which would have constituted, to borrow Peter Gatrell's term, early medieval 'refugeedom' (cross reference Gatrell). This article thus aims to elucidate part of the web of cultural assumptions and legal structures which - in an age without rigid 
rules about citizenship - distinguished locals from outsiders, because doing so provides important context for understanding two subjects relevant to the concerns of this volume: both the logic underlying the refuge functions of churches and the difficult position which refugees are likely to have occupied in Anglo-Saxon society.

\section{Ecclesiastical Sanctuary}

First, some background on ecclesiastical sanctuary and how it has been approached by medieval historians. The refuge function of churches in the Middle Ages was underpinned by ideas drawn from a range of sources. It originally developed in the context of the late Roman Empire, in a fusion of secular aristocratic practices of intercession on behalf of clients with the pastoral concerns of churchmen keen to ensure that wrongdoers were not, through execution, denied the opportunity to do penance for their sins and attain salvation (Shoemaker 2011: chs. 1-2). The sanctuary practices that emerged from this context owed relatively little to the explicit biblical model of 'cities of refuge' visible in several books of the Old Testament, though this did become significant in some later strands of thought (Shoemaker 2011: 53-5). However, it is important to note that at least in England, at no point in the medieval period - from conversion in the seventh century to sanctuary's demise in the 1540s - did the right to refuge in churches recognised in secular law correspond at all closely with ecclesiastical models. It was not, as might be assumed, simply that strong kings were unwilling to recognise the Church's claims to protect wrongdoers from the full rigour of the law; the misalignment was deeper than that, with legal protections frequently falling short of ecclesiastical ideals in some respects - for example, in allowing sanctuary-seekers to be punished in supposedly unacceptable ways - whilst exceeding them in others, such as in allowing protection to supposedly excluded categories of wrongdoer (Lambert 2012b).

The underlying reason for this is that traditions of refuge in churches also drew on a web of ideas and values that owed little to Christian doctrine, or indeed to the legacy of Rome, the contours of which - much more so than learned ecclesiastical thought on the subject - remain relatively obscure in modern scholarship. In England, at least, this observation pertains particularly to the earlier medieval period on which this article focuses, because in the late twelfth century the institution of sanctuary assumed a fixed form which would remain largely unchanged until its abolition in the 1540 s - a form which was an important part of the fabric of the English legal environment, accommodated and exploited in various ways, but increasingly detached from broader social values and assumptions (Lambert 2012b: 117-23). In the earlier period, by contrast, ecclesiastical sanctuary had clear secular analogues; it made sense as part of an ecology of ideas visible in the Anglo-Saxon legislative tradition. The existence of a non-religious context for ecclesiastical sanctuary in this period has to some extent been recognised by modern historians. It has tended to be understood as a practical aspect of dispute-resolution processes (sanctuary providing a period of peace in which settlements could be negotiated in feuds) and as an expression of the power of kings, which underpinned the protection churches offered (Riggs 1963, Hyams 2003: ch. 3, Shoemaker 2011: ch. 5). To the extent that sanctuary has been treated as a reflection of essentially secular ideas, it has been seen as an institution designed specifically for peace-making purposes, and thus a manifestation of the 'strong conciliatory ethic' that characterises at least some aspects of early medieval law (Shoemaker 2011: 50). I do not wish to challenge the accuracy of this assessment here but rather to flesh it out: the treatment of refuge in Anglo-Saxon law (in churches and elsewhere) often makes sense in the context of reconciling enmities, but this article will argue that anxieties about outsiders - simultaneously threatening and vulnerable figures - and the notion of hospitality 
can provide a fuller, more satisfying context for the legal protections available to those seeking refuge in early medieval English society.

\section{The Anglo-Saxon Period}

Before we turn to the evidence itself, a very brief sketch of the Anglo-Saxon period and its evidencebase may be helpful. Politically, this period saw considerable change. In the seventh century most (but not all) of the area we think of as England (and much of what we now regard as southern Scotland) was ruled by kings who can reasonably be termed 'Anglo-Saxon' or 'English': rulers of peoples who traced their origins to various obscure Germanic migrant groups - mostly from what Peter Heather (cross reference Heather) helpfully terms the 'outer periphery' of the Roman Empire - which crossed the North Sea in the period after the collapse of Roman Britain in the early fifth century. These kings' kingdoms were relatively small and numerous at this stage, though powerful overlords could assemble large alliances of subordinate rulers for military expeditions. Larger kingdoms tended to absorb smaller neighbours over time, reducing the number of independent kingdoms drastically by the ninth century, and only one of these - Wessex - was able to endure the large-scale Scandinavian attacks of the late ninth century. In the tenth century, the West Saxon royal house took advantage of the destruction of its English rivals, extending its domination over most of the territory they had once ruled and creating in the process a single kingdom of England (Yorke, 1990, Molyneaux 2015). This kingdom was to be conquered by Duke William of Normandy in 1066, the conventional end-point for the Anglo-Saxon period of English history.

Throughout this period the vast majority of the population were engaged in mixed agriculture, though there was a gradual and incomplete shift in the balance from primarily pastoral farming at the start of the period to more intensive arable production at its close. Urbanisation was initially limited - a handful of coastal trading settlements serving as centres for the import of elite luxury goods - but relatively rapid economic growth, especially from the late tenth century, led to the emergence of a network of small market towns by the end of the period. The evidence for social structure is difficult, but the earliest laws imply that the Anglo-Saxons understood themselves as a society of free farmers, working their own land with the help of slaves and the landless free population. A very wealthy aristocracy, defined at least in part by personal military service in royal households, was supported by the food renders and labour services which these free farming households owed to the king (in proportion to the amount of land they held). There were thus always significant disparities of wealth in this society but these probably became noticeably greater as the period progressed, with the aristocracy becoming more entrenched and numerous and the number of independent free farming households declining. (That such a shift took place is generally accepted but its significance and timing are disputed, see Faith 1997: 123-5, cf. Wickham 2005: 34750.)

On legal matters, the Anglo-Saxons had a strong tradition of local communities assembling to issue authoritative judgements in legal disputes; the coercive power underpinning these judgements was largely drawn from a combination of the offended parties (violent vengeance was a legitimate element of legal practice) and collective expeditions mounted by communities. The laws assume the latter to be the ultimate sanction against wrongdoers whose offences were understood to warrant punishment in addition to any compensation owed to victims (theft, in particular, was a major focus of communal concern). Kings were always potential sources of coercive power in cases where they had particular interests, but the first evidence that royal officials were expected to be responsible for 
routine law-enforcement does not appear until around the year 1000 (Lambert forthcoming, ch. 6). Our main sources for legal matters in this period are texts of laws, mainly but not exclusively issued by kings. We have an early cluster of four texts, three Kentish and one West Saxon, from the period c. 600-725 and significantly larger late Anglo-Saxon corpus from the period c. 890-1020. These later texts almost all represent English law, which emerged from the West Saxon legal tradition, as opposed to the much more obscure Scandinavian legal customs that applied in what came to be known as the Danelaw (comprising, roughly, East Anglia, the East Midlands and Yorkshire). Because we have very limited records of actual cases - and because those records are unrepresentative, being overwhelmingly concerned with disputes involving the aristocratic elite and landed property there is significant uncertainty about how the rules recorded in these law texts relate to practice (Wormald 1999). They are, however, excellent sources for the way contemporaries thought about law, and about their own society more generally, which is what this article seeks to explore.

\section{Communities and Outsiders}

If a stranger or man from afar quits the road and neither shouts nor blows a horn, he shall be assumed to be a thief and as such may be either slain or put to ransom (Wi 28 , Ine 20 ). ${ }^{2}$

This passage, which occurs in laws from both Kent and Wessex in the late seventh century, is often used to illustrate the hostile attitude of Anglo-Saxon society to outsiders, who are clearly regarded as problematic and potentially threatening figures. This may well have relatively little to do with any Anglo-Saxon cultural tendency towards xenophobic attitudes, and rather more to do with the basic fact that outsiders were - by definition - not integrated into local networks of mutual suretyship and shared responsibility that shaped legal practice and to a significant extent constituted community membership in this period (Taylor 2014). If a stranger caused harm in a locality and then fled the area there was little that anyone could do about it, no obvious avenue through which an aggrieved party might seek redress. Strangers posed a threat.

The situation for local people was different. This is most obviously illustrated by the case of homicide. Our earliest evidence for English law - the essentially pre-Christian tariff of compensations put into writing at the behest of King KEthelberht of Kent shortly after his conversion around the year 600 - is generally at pains to emphasise that individuals ought to take responsibility for their own misdeeds (Abt 30). Nonetheless, the shared liability of families is made plain in a passage which considers a situation in which a man killed and fled the country: the killer's family were still liable to pay half the victim's wergild - the formal value his life, payable to a dead man's kinsmen in cases of homicide (Abt 23). The general expectation that families share responsibility for individuals' wrongdoing is thrown into relief in passages which consider problematic situations in which offenders lacked a full set of relatives. The late ninth-century laws of King Alfred consider the possibility that a free man who killed might not have paternal kinsmen: in such a situation, they state, his maternal kinsmen were liable for a third of the wergild and his gegildan the other third - if unable to pay the final third personally the killer must flee into exile. If the killer had no kinsmen at all his gegildan were liable for half the wergild (Af 30-30:1). The gegildan are obscure (the word means 'associates' or, more precisely in certain contexts, 'fellow guild members') but they are evidently functioning as substitute kinsmen here: men lacking in local kinsmen were clearly expected somehow to form bonds of mutual suretyship with others to make up, at least partially, for the deficit. (One text from around the turn of the millennium sets out the regulations of an aristocratic 
guild in Cambridge that did something similar but we can only speculate as to how representative these regulations might be; see Thorpe 1864: 610-13.)

One of the key features of an upstanding local freeman, then, was that he had local relatives who shared liability for his actions, people who could be made to pay compensation if he caused harm and fled the area. Even local men who lacked relatives were thus potentially troubling, but the construction of artificial mutual suretyship groups to substitute for absent kinsmen could solve the problem to an extent. Other potential sources of anxiety were the unfree, who almost by definition lacked free relatives who could be held responsible for their actions. The solution here, however, was simple: their owners were liable for their actions if they fled (HI 1-4). Landless free people, who perhaps might sometimes live and work in households distant from their families, were dealt with similarly: a late seventh-century law explains if there were no other sureties (presumably a reference to kinsmen or substitute kinsmen) the heads of the households in which such people worked were liable to make good the value of any goods they stole, should they escape the area (Ine 22). Later, in the early tenth century, one law suggests anxiety about landless men serving in districts far from their family homes - most plausibly read as a reference to young warriors serving in the households of powerful political figures - insisting that whenever they returned to their native districts to visit their families, the head of whichever household they were staying in took full responsibility for their behaviour, to the extent of paying any compensation they incurred (II As 8). If the reciprocal bonds of kinship (real or artificial) were unavailable, then, another way of safely embedding potentially threatening people in a locality was through more hierarchical arrangements: they could enter a subordinate relationship with an immediate superior, who would in return accept liability for their compensation payments should they commit an offence and flee. This is how Alfred's laws, at the end of the ninth century, deal with foreign traders: they insist that the leader of any group take personal responsibility for all the others, ordering that he present them to a communal assembly in the presence of a royal official and guarantee that he can produce them at such an assembly in the event of their being accused of wrongdoing (Af 34).

Though it is not always made explicit, the structuring concept in these hierarchical bonds is that of the household. Heads of household were evidently understood to have accepted a degree of responsibility for all resident dependants' behaviour when they accepted them into their homes, even if (especially in the earlier evidence) this is often only as a backup in cases not covered by reciprocal bonds on the model of kinship. This relationship between head of household and dependant is the model on which bonds of personal lordship are based (on different forms of lordship, see Baxter 2007: ch. 6). This is visible etymologically. The Old English word from which we get 'lord', hlaford, derives from hlaf-weard: 'loaf-guardian'; this can be juxtaposed with hlafæta, a rare early word for 'dependant' which literally means 'loaf-eater'. The very language of lordship is rooted in household relationships. Heads of households were necessarily lords to dependants who lived in their homes but they could also choose to bind themselves as lords to non-resident dependants, recognising them as members of what was essentially a metaphorical household. By the early tenth century, at least, it seems that such relationships were coming to be regarded as an essential aspect of safely integrating potentially troublesome individuals into local communities. Laws from the reign of King Æthelstan (924-39) express anxiety about 'lordless men from whom no justice can be obtained', ordering that the kinsmen of any such man find a lord willing to accept him, a process of persuasion which - if the man in question was notoriously untrustworthy - could involve formally indemnifying the lord against the liabilities he was accepting (II As 2-2:1; III As 7:2). 
Even if financial liability ultimately rested with the family, then, by this point it was perceived as important that every man be bound into the metaphorical household of a nobleman - a figure of sufficient wealth and status to be relied upon to provide proper compensation for victims should the offender himself flee.

Outsiders, by definition, were people who lacked local connections. Because they were not bound into the locality by reciprocal ties of kinship (real or artificial) or by the hierarchical structure of the household (real or metaphorical), they represented a potential threat in a very real sense. The possibility of their committing an offence and fleeing was much more dangerous than for local figures because it would leave offended parties with no reliable avenue for redress. And because strangers' characters were unknown, locals could not rule out the possibility that their intentions were hostile. The most obvious theme running through Anglo-Saxon legal texts is the hatred and fear of thieves: men who not only take other people's property but make every effort to conceal their responsibility, and thus to leave victims with no hope of recouping their losses (Lambert 2012a). It is not surprising that the stranger, his intentions suspect and with no local ties through which he might be pursued, raised the spectre of theft; a stranger actually caught behaving furtively - failing, as the law quoted above envisaged, to announce himself in a place he had no reason to be - was so obviously threatening a figure that he did not deserve a second chance. Such strangers presented a clear danger not just to the individuals who found them sneaking around but to all their neighbours; to capture or kill one was a service to the community as a whole.

The other side of this coin, of course, is that people travelling in places where they were outsiders were in an extremely vulnerable position. If they made a point of demonstrating their honest intentions - for instance by blowing a horn or shouting to make their presence known if they ever found themselves in a location where their presence might be regarded as suspicious - they may have been unlikely to encounter open hostility, but they would probably have had little reason to expect more than a cautious reception in places where they unable to claim even a tenuous connection to a local figure. The lack of solid, legally recognised bonds which made outsiders threatening to locals likewise made locals threatening to outsiders. This is because the same relationships which obliged kinsmen and pseudo-kinsmen to accept liability for one another's misdeeds also provided them with protection. To take the most extreme scenario, killing a free man was a grievous affront to his kinsmen, who (unless they were willing to be openly mocked for their cowardice) had little option but to pursue the matter vigorously, either taking violent vengeance against or exacting a large compensation payment from the killer and those bound to support him. The knowledge that this was the case provided an obvious deterrent to harming people, the effect of which must have been much greater for those with local families than for those whose relatives were distant and less directly threatening. Heads of household and personal lords were in a similar position to families: entitled to compensation for harm done to those under their protection and honour-bound to take action to extract it. The sums involved were generally much smaller Fthelberht's laws (c. 600) state that a freeman's wergild was 100 shillings, whereas the sum paid to a free householder for killing his dependant (hlafæta, 'loaf-eater') was only 6 shillings - but the principle was the same (Abt 21, 25).

The vulnerability of those who, for whatever reason, lacked the protection that came with household and kinship bonds is clearly recognised as a problem in the laws. One late seventhcentury passage, considering the possibility of emancipating a slave, is particularly revealing on this 
point. The freed slave, because he lacked a free kindred and was no longer bound to a particular household, was in a dangerous position: as no-one had a duty to protect him there was little to deter others from harming him, even killing him. The law's solution to this problem was to assert that the emancipator continued to be bound to his former slave as a protector, entitled to his wergild should he be killed (Wi 8). The discussion of the liability for killings committed by men who lacked kinsmen in the late ninth-century laws of Alfred, interestingly, is immediately followed by the statement that if such a man was killed - one with no relatives whatsoever - his wergild was to be divided between his gegildan and the king (Af 31). Again we see the expectation that those who lacked kinsmen would somehow bind themselves to substitutes, but also the idea that the king had a particular duty to step in to protect the vulnerable. This is most clearly articulated in an early eleventh-century text:

If any attempt is made to deprive a ... stranger of either his goods or his life, the king (or the earl of the region) and the bishop of the diocese shall act as his kinsmen and protectors, unless he has some other. And such compensation as is due shall promptly be paid to Christ and the king according to the nature of the offence; or the king ... shall avenge the offence (EGu 12).

The main message to take from this evidence, it seems to me, is that the vulnerability of outsiders was a recognised problem, and a particular concern for churchmen (all the relevant evidence appears in laws notable for their strong Christian flavour). The ecclesiastical ideal may well have been for kings to act as guardians for the weak and for emancipated slaves' former masters to take their protective responsibilities seriously, but in the absence of evidence bearing on whether this was realised in practice we probably ought to be sceptical. Likewise, one (again obviously ecclesiastical) law text asserts that strangers ought to be able to deny legal accusations by simply swearing an oath at an altar, according them the same privilege as a member of the king's own household (Wi 20). This makes sense because strangers would have been in no position to do what was normally required to deny a charge, which was to assemble a specified number of upstanding local men willing to support an oath of denial with an oath of their own, but the expectation that local assemblies would willingly accept the unsupported word of a suspicious stranger in such circumstances may well have been rather idealistic.

\section{Hospitality and Its Limits}

The central point here is that the Anglo-Saxon laws suppose a world in which protection and responsibility go hand in hand as the key legal manifestations of the social relationships by which local people were embedded in their communities. The bond of kinship obliged men, in effect, to act as sureties for their relatives - potentially incurring substantial liabilities for compensation payments - but it also made them protectors, entitling them to receive compensation when one of their number was killed (and perhaps, though this is obscure, to share in compensation payments for lesser offences). Hierarchical relationships modelled on the household worked in the same way: they meant that personal lords and heads of household accepted some responsibility for their dependants' misbehaviour, but they also established a duty to protect which - though it came with the obligation to take action - could lead to financial benefits. Outsiders were problematic figures, simultaneously threatening and vulnerable because they lacked such relationships; they were neither protected from harm, nor did local communities have any assurance that harm they caused would be rectified. The only wholly satisfactory way to overcome these issues was to integrate outsiders into these local structures, attaching them permanently to local households and kindreds 
(or forming substitute kinship ties like those represented by the obscure gegildan of Alfred's laws). That is to say, the problems posed by outsiders could only be solved fully if they ceased to be outsiders and became locals.

A more temporary solution was provided by hospitality: it went some way to solving the problems posed by threatening and vulnerable outsiders, but it raised issues of its own in the process. (For a recent discussion with references to earlier scholarship, see Gautier 2009.) From the outsider's perspective, the benefits of hospitality were obvious: as well as providing food and shelter, hosts were understood to act as protectors to people they invited into their homes. This principle is visible from our earliest evidence onwards. The laws of Æthelberht of Kent (c. 600) are clear that killing someone in the house of either the king or a nobleman required compensation to be paid not just to the slain figure's family but to the owner of the house they were in when they were killed (Abt 5, 13). Ordinary free men are not mentioned in that text, nor is the treatment of offences other than killing, but these are addressed in detail in our next set of Kentish laws, written in the 680s. Not only are violent acts within houses represented as an offence against their owners, but also insulting and provocative behaviour: snatching a drinking cup from a fellow guest, verbally insulting him, or drawing a weapon (even if ultimately no harm was done). Lesser sums are specified for these more minor infractions of a host's protection, but 'if the house becomes bloodied' the owner was entitled to his full mundbyrd - the financial value of his protection, which varied according to status (HI 1114). To harm or even to act provocatively towards a guest was to insult the host, to breach his protection in a way which required compensation.

Inviting an outsider into one's home was thus a way of offering him security; the relationship between host and guest to some extent bound the outsider into the host's household, rendering him much less vulnerable. Although the formal protection provided was relatively small - the compensation that would be owed to the host in the event of a guest being killed would be far less than the full wergild owed for a local freeman - the practical security provided was probably rooted in qualitative social logic rather than quantitative legal calculation. To harm another man's guest in a drunken argument was one thing - a forgivable lapse of judgement in the heat of the moment, perhaps, providing due compensation was paid - but to seek him out in order to cause harm would be a deliberate and serious insult of the sort that, regardless of its financial consequences, could permanently end good relations between neighbours.

A host's offer of hospitality probably, except in unusual circumstances, eliminated the threat posed to his guest by other locals. But to what extent did hospitality end the threat posed by the outsider to the locality? In social terms it probably provided some degree of reassurance. The host's provision of hospitality ought to be understood as a form of gift - not just of food and shelter but of protection - and this put the guest under an obligation to reciprocate, which as an outsider was a difficult thing to do. Making any form of trouble for one's host would effectively be to throw his hospitality back in his face, repaying his kindness with an insult. Any guest with a sense of honour would understand a host's hospitality as imposing an obligation to behave appropriately during his stay in the locality, and this probably meant that when a local householder accepted a potentially threatening stranger into his home his neighbours' concerns diminished to some extent.

What hospitality did not do, however, was formally transfer liability for a guest's misdeeds to the host. The laws explicitly state that such liability only came into existence once the relationship 
between host and guest became so long-standing that it no longer qualified as mere hospitality. This is from the laws of Kings Hlothhere and Eadric of Kent, issued in the 680s:

If a man entertains a stranger (a trader or any other man who has come across the frontier) for three nights in his own home, and then continues to provide him with food, and if he [i.e. the stranger] does harm to anyone, the man [i.e. the host] shall bring the other to justice or make amends on his behalf. ( $\mathrm{HI} 15$; see also II Cn 28, ECf 23:1)

Hospitality was by definition a temporary arrangement. For three days the link between protection and responsibility that characterised Anglo-Saxon socio-legal bonds did not apply: hosts protected their guests like members of their households, but they did not become liable for any harm that they did. Once those three days were up, however, the relationship had to be normalised: the guest needed either to leave or to become a full member of the host's household, with both parties accepting the obligations that entailed.

\section{Hospitality and Refuge}

I would suggest that this aspect of hospitality - the householder's right to offer a guest protection without becoming liable for his offences, albeit only for a limited period of time - underlies the use of both houses and churches as places of refuge in this period. Most Anglo-Saxon laws on this subject have essentially the same features: they recognise various figures' right to offer protection to fugitives without assuming liability for whatever they had done to provoke pursuit, but only for a limited time. It is important to note that there are two contrasting contexts in which the laws discuss this refuge function, and that the way it is presented is conditioned by these contexts.

On the one hand there is the context of feuding: one group has been affronted and is seeking vengeance (perhaps but not necessarily for the death of a family member) and the person they are pursuing flees to a house, a church or to a powerful nobleman for protection. In this context, the laws view the protection provided very positively: the ideal outcome in such a situation is not violence, which could beget further violence in retaliation, but a negotiated settlement in which the party seeking vengeance is persuaded to accept compensation instead. A temporary period of protection in which tempers could be cooled and negotiations begun was an entirely positive contribution to this goal. The laws of Alfred, from the late ninth century, provide a highly detailed scheme for how this was meant to work, which is applied to both houses and churches. Those who know their enemy to be at home, or pursue him to a church, are not to attack him within until they have demanded justice (i.e. compensation), and even then they are not to breach the confines of the house or church. Rather, they are to besiege him within for up to seven days, after which he is to surrender himself into their custody on the conditions that he remain unharmed for a further thirty days and that his kinsmen be informed of his situation, providing them with the opportunity to negotiate a settlement (Af 5-5:3, 42-42:3). Eventually, in the mid-tenth century, the protection offered by any and every house was given powerful royal backing: attacking someone in a house was defined as hamsocn and treated as a breach of the king's personal protection (II Em 6; Lambert 2012a: 27). The laws' evident enthusiasm for protection in this context ought to make us cautious in their interpretation; in particular, it is possible that Alfred's elaborate scheme of seven days' protection followed by thirty as a hostage represents idealistic thinking rather than any practical reality (in the case of houses, in particular, the absence of any penalties for failing to follow the procedures outlined provides grounds for suspicion). 
The other context in which a fugitive might attempt to use a church or house as a refuge is more revealing because law-makers' attitude to it was essentially hostile. There were certain offences theft is by far the most prominent - which were understood not merely to harm their immediate victims but to pose a serious threat to the community as a whole. Rather than a peaceful compensation settlement between the parties, the ideal in such cases was harsh punishment; this led some laws to treat people who gave hospitality to fugitives as offenders in their own right. For instance, the laws of Ine of Wessex (688-726) state that those unable to deny having knowingly sheltered a fugitive are to forfeit their own wergilds - the value of their own lives - to the king, and several laws from the reign of $Æ$ thelstan (924-39) threaten those who harbour fugitives of various types with severe punishment (Ine 30; II As 2-2:2, 20:8; IV As 3-3:2; V As Prol 1- Prol 3).

Another of $Æ$ thelstan's laws, however, goes into considerably more detail on this point:

And we declared in the assembly at Thunderfield that if any thief or robber fled to the king, or to any church, or to the bishop, he should have a respite of nine days. If he flees to an ealdorman [a great magnate], or an abbot, or a thegn [a nobleman], he shall have respite of three days. If anyone slays him within that period of respite, he shall pay as compensation the mundbyrd [protection-value] of the protector.... But let [the thief] seek what protection he may, his life shall be spared only for as many days as we have declared. And he who harbours him longer shall be liable to the same treatment as the thief (IV As 6-6:3).

This law is important because it is somewhat absurd. It imagines thieves fleeing to the protection of various noble figures, being entitled to succour, but being handed over for execution as soon as a three- or nine-day period had elapsed. It is hard to imagine that, in practice, the noble figures in question would not recoil from the idea of surrendering supplicants to their deaths. This is clearly a law intended to override any such objections in order to achieve the higher goal of ensuring that known thieves did not escape execution. What is interesting about it is that, in spite of this evident agenda, it accepts the legitimacy of limited periods of refuge: it may have been thinkable to put noble protectors in this difficult position, but their right to offer protection to whomsoever they wished for a limited time could not legitimately be challenged. It seems likely that behind this law lay conflict: a major royal anti-theft campaign having to acknowledge and work around the legitimate objections of aristocrats concerned to maintain their protective rights.

This has two important implications. The first, simply, is that it implies that at least some early tenthcentury aristocrats regarded their right to offer protection as sacrosanct - something worth raising as an almost certainly unwelcome obstacle to a powerful king's legislative programme. The second is that, when pared back to its bare minimum by law-makers who (in this particular context) regarded it as an inconvenience, the right to offer refuge to fugitives clearly boils down to the standard legal right to offer hospitality. As we have seen, a host could offer a guest food, shelter, and protection for up to three days without incurring liability for his wrongdoing, but after that period has elapsed he either had to send him on his way or take responsibility for him. The rights of ealdormen, abbots and thegns, as outlined in Athelstan's laws, follow this model precisely, even down to the three-day time-limit. Kings, bishops and churches can protect for longer, but there is no qualitative distinction: it is simply that their rights are greater as befits their higher status. The right to offer refuge to wrongdoers was at root the right to offer hospitality. Moreover, it was a matter of considerable 
cultural importance that aristocrats be able to offer hospitality, and the protection that went with it, to people who feared for their lives - even figures as generally despised as thieves.

Why should this be? The implication, I suspect, is that a nobleman risked dishonour if he refused a plea for hospitality from someone in danger of being killed, because such a refusal could readily be interpreted a sign of weakness or even cowardice, an admission that he feared to defy the fugitive's pursuers. Hospitality in its ideal form was an act of generosity undertaken voluntarily by a host with no moral obligation to his guest, and at some risk to himself (Shryock 2008); prohibiting honourable men from behaving in this way was unacceptable. This would fit well with wider discourses on hospitality and honour (Kerr 2002, cf. Gautier 2009) but it is surprisingly difficult to prove with the evidence available. A strong hint in this direction is provided by an early eleventh-century law prohibiting various people from entering the presence of the king:

And if secret murderers or perjurers or open killers presume so far as to remain anywhere close to the king, before they have made amends to both God and the world, they shall be in danger of losing their lands and goods, unless they are peace-supplicants (VI Atr 36).

The underlying logic here is probably that people who commit grievous sins and refuse to do penance represent dangerous spiritual pollutants, capable of tainting those who associate with them. They are not only to be kept away from the king, as here, but excluded from burial with other Christians and (in more rhetorical passages, at least) cast out of the land entirely. The king in particular needed to avoid being tainted by association because his kingdom's wellbeing was understood to depend to some degree on his maintaining a favourable relationship with God (Lambert forthcoming, ch. 5). Kings thus had good reason to want to avoid contact with deeply sinful and unrepentant people. Why, then, the exception for 'peace-supplicants' (friðbena)? The implication seems to be that the king will make an exception to this general exclusion from his presence for people who are seeking his protection, presumably because they fear violence of some sort. If this is the correct interpretation, this passage shows that the king's duty to offer hospitality and protection to people in danger was so important that it compelled him to offer refuge to people who, in normal circumstances, he would not have tolerated in his presence.

\section{Conclusions}

What, then, does this tell us about the history of refugee protection? On one level it is significant because of its implications for traditions of ecclesiastical sanctuary: in early medieval England, at least, these appear to have been shaped at least as much by secular ideas about honour and hospitality as by religious doctrine. It is not that explicitly Christian discourses on sanctuary are entirely absent in laws from this period, as there are a few passages which treat sanctuary as a pastoral tool in a way that aligns well with sanctuary's late antique roots: as a means by which grievous sinners' lives could be spared, giving them time to undertake penance and thereby attain salvation (Ine 5, WI 1, ECf 5-5:3). However, the understanding of hospitality as a necessarily temporary relationship in which a host provides a guest with protection without accepting responsibility for his actions is, I would contend, the best explanation for the time-limits on refuge in churches that dominate Anglo-Saxon sanctuary law, and indeed would later characterise the standard right of sanctuary in English churches that lasted from the late twelfth century until the Reformation (Lambert 2012b). The broader point here for Refugee Studies, perhaps, is that if medieval traditions of sanctuary in churches really were precursors to modern political asylum - a 
notion to which the essays in this volume, at least, offer little direct support - these traditions ought to be understood as reflections of deeply rooted secular values and practices surrounding honour and hospitality, not simply as expressions of the fervent religiosity that modern observers tend to expect of the medieval period. The values underpinning early medieval sanctuary were not, in fact, very different from those expressed by Lord Palmerston, as quoted in Phil Orchard's contribution to this volume (cross reference Orchard), and they are far from unique to Christian cultures (e.g. Dresch 1989: 53-65).

The bigger point, however, is not about churches at all. Anglo-Saxon refuge practices were products a world in which permanent membership of a community was established through legally binding social relationships - both the reciprocal ties of kinship and the more hierarchical bonds modelled on the household - which both protected individuals from harm and ensured the existence of local sureties obliged to make good any harm they did. Hospitality severed the link between protection and responsibility, allowing hosts to protect guests without having to stand surety for them. Such exceptional relationships were problematic and could only be allowed to persist temporarily. That they were allowed to exist at all must in part come down to the basic need to socialise with neighbours without becoming liable for their misdeeds. Nonetheless, the importance attached to extending hospitality and thus protection to people in danger - even thieves - suggests that something more was at stake. Honourable men were meant to be generous and hospitable; though it would be rather naïve to imagine that the early medieval Englishmen valued hospitality to the extent that all requests for food and lodging had to be accepted on pain of incurring dishonour, the implication does seem to be that refusing hospitality to the extremely vulnerable - people who faced death if they were not taken in - was the sort of cowardly act the Anglo-Saxon elite tended to judge harshly. That is to say, there is good reason to think that the Anglo-Saxons had a similar 'humanitarian' ethos to that which Benjamin Gray discerns in Greek tragedies in his contribution to this volume: a belief that when the stakes were high, the powerful were honour-bound to offer protection to the vulnerable (cross reference Gray).

It seems likely that these ideas and values were deeply rooted in Anglo-Saxon society. They are implicit in our earliest evidence and they become more explicit later on: the significance of hospitality in underpinning refuge functions is much more clearly articulated as a result of those refuge functions coming into tension with the priorities of more aggressive tenth-century royal legislation. However, it is also probably true to say that this late Anglo-Saxon legislative activism had an effect on attitudes to legitimate sources of protection. Early tenth-century laws, as we have noted, recognise that various types of noblemen have a right to offer what amounts to hospitality even to thieves, but they do not concede this to ordinary freemen. Similarly, the mid-tenth-century extension of powerful royal protection to all houses would theoretically have made hosts' protection of their guests against external aggressors much less relevant, particularly at the lower end of the social spectrum (II Em 6; Hn 80:10-80:12). What we may be seeing is the beginning of a long-term trend towards a restriction of the right to offer refuge to fugitives: what had probably begun as a general right, a by-product of every free householder's ability to offer hospitality, seems to have been coming to be regarded as a privilege of a social elite in the tenth century, and it was certainly limited to churches by the later medieval period. Today we tend to assume that the right to offer refuge to fugitives is a by-product of territorial sovereignty, its legitimate manifestation being the concept of 'political' asylum. In England, at least, the gradual process by which this came to seem a self-evident truth may have begun in the Anglo-Saxon period. 
How, then, were refugees treated in Anglo-Saxon England? As was noted at the start, we cannot really know, but the ideas surveyed here at least allow us to make some solidly educated guesses. It seems likely that Anglo-Saxon communities would initially have found an influx of refugees strangers with no local attachments - very threatening. There may well have been a serious risk of open hostilities erupting in such circumstances, but providing this was avoided it is unlikely that the locals would have thought it acceptable to allow the refugees to starve, and they probably would have tried to ease tensions in the short term with offers of hospitality. This could only be a temporary measure, however, and in the medium term this would probably have given way to the subordination of the refugees through their integration into local hierarchical structures of household and lordship. Potentially this could have involved some high-status refugees serving as warriors in great royal and noble households, but most - if they lacked the economic means to set themselves up independently and were unable to dominate their hosts militarily - would presumably have had to accept dependent ties to lords of one sort or another, just like the poorest stratum of Anglo-Saxon society. One late seventh-century law implies that those who are given not just land by a lord but also provided with a house become tied to him permanently, losing their right to leave (Ine 67). For the lowliest, integration may well have involved a form of enslavement. (For an interesting anthropological parallel to such a process, see Colson 1970). In the long run, perhaps, inter-marriage would have formed kinship bonds between the refugees and their hosts, contributing (as part of a broader pattern of cultural assimilation) to the erosion of the distinction between locals and incomers. This, at least, seems to be the general trend in this period: ethnic differences that mattered in the seventh century, such as that between Britons and the English in Wessex, fade into obscurity by the tenth. This is all speculative, of course, but this sort of analysis at least allows us to approach the history of refugee protection in this period.

\footnotetext{
${ }^{1}$ I would like to thank Olaf Kleist for organising the seminar series and workshop that led to this special issue and the other participants for their thought-provoking contributions. Though I was unable to produce a draft in time for him to comment on it directly this paper owes a great deal to conversations with Paul Dresch over five years in Oxford.

${ }^{2}$ Anglo-Saxon laws are cited using the now-standard system of abbreviations established in Liebermann 18981916. English translations of most texts can be found in Attenborough 1922 and Robertson 1925. The online 'Early English Laws' database (http://www.earlyenglishlaws.ac.uk/) also provides a comprehensive listing of texts and their published editions and translations.
}

\section{Works Cited}

Attenborough, F. L. (1922) The Laws of the Earliest English Kings. Cambridge: Cambridge University Press.

Baxter, S. (2007) The Earls of Mercia: Lordship and Power in Late Anglo-Saxon England. Oxford: Oxford University Press.

Campbell, J. (2010) 'Secular and Political Contexts'. In DeGregorio, S. (ed.) The Cambridge Companion to Bede. Cambridge: Cambridge University Press, pp. 25-39.

Colson, E. (1970) 'The Assimilation of Aliens among the Zambian Tonga'. In Cohen, R. and Middleton, J. (eds.) From Tribe to Nation in Africa: Studies in Incorporation Processes. Scranton, Pennsylvania: Chandler Publishing Company, pp. 35-54. 
Dresch, P. (1989). Tribes, Government and History in Yemen. Oxford: Clarendon Press.

Faith, R. (1997) The English Peasantry and the Growth of Lordship. Leicester: Leicester University Press.

Gautier, A. (2009) 'Hospitality in Pre-Viking Anglo-Saxon England'. Early Medieval Europe 17(1): 2344.

Hyams, P. (2003) Rancor and Reconciliation in Medieval England. Ithaca, New York: Cornell University Press.

Kerr, J. (2002) 'The Open Door: Hospitality and Honour in Twelfth/Early Thirteenth-Century England'. History 87(287): 322-35.

Lambert, T. B. (2012a) 'Theft, Homicide and Crime in Late Anglo-Saxon Law'. Past and Present 214(1): 3-43.

Lambert, T. B. (2012b) 'The Evolution of Sanctuary in Medieval England'. In Dresch, P. and Skoda, H. (eds.) Legalism: Anthropology and History. Oxford: Oxford University Press, pp. 115-44.

Lambert, T. B. (forthcoming) Law and Order in Anglo-Saxon England. Oxford, Oxford University Press.

Liebermann, F. (1898-1916) Die Gesetze der Angelsachsen. 3 vols., Halle: Max Niemayer.

Molyneaux, G. (2015) The Formation of the English Kingdom in the Tenth Century. Oxford: Oxford University Press.

Matthew E. Price (2009) Rethinking Asylum: History, Purpose, and Limits. Cambridge: Cambridge University Press.

Riggs, C. H. (1963) Criminal Asylum in Anglo-Saxon Law. Gainesville, Florida: University of Florida Press.

Robertson, A. J. (1925) The Laws of the Kings of England from Edmund to Henry I. Cambridge: Cambridge University Press.

Shoemaker, K. (2011) Sanctuary and Crime in the Middle Ages, 400-1500. New York: Fordham University Press.

Shryock, A. (2008) 'Thinking about Hospitality, with Derrida, Kant, and the Balga Bedouin'. Anthropos 103: 405-21.

Taylor, A. (2014) 'Lex Scripta and the Problem of Enforcement: Anglo-Saxon, Welsh and Scottish Law Compared'. In Pirie, F. and Scheele, J. (eds.) Legalism: Community and Justice. Oxford: Oxford University Press, pp. 47-76

Thorpe, B. (1864) Diplomatarium Anglicum AEvi Saxonicum: A Collection of English Charters from the Reign of King Athelberht of Kent to that of William the Conqueror. London: Macmillan.

Wickham, C. (2005) Framing the Early Middle Ages: Europe and the Mediterranean, 400-800. Oxford: Oxford University Press. 
Wormald, P. (1999) The Making of English Law: King Alfred to the Twelfth Century. Volume I: Legislation and Its Limits. Oxford: Oxford University Press.

Yorke, B. (1990) Kings and Kingdoms in Early Anglo-Saxon England. London: B. A. Seaby. 